\title{
Analisis Undang-Undang Nomor 40 Tahun 2014 Tentang Perasuransian Terhadap Jaminan Sosial Korban Kecelakaan Lalu Lintas di PT. Jasa Raharja (Persero) Cabang Jawa Tengah
}

\section{Cahya Primarta*}

\begin{abstract}
Mahasiswa Program Magister (S2) IImu Hukum Fakultas Hukum UNISSULA Semarang, email cahyanyaindah@gmail.com
\end{abstract}

\begin{abstract}
ABSTRAK
PT. Jasa Raharja (Persero) salah satu Badan Usaha Milik Negara yang ditugaskan pemerintah untuk mengelola Dana Pertanggungan Wajib Kecelakaan Penumpang dan Dana Kecelakaan Lalu Lintas Jalan sebagai pelaksanaan UU No. 33 dan 34 Tahun 1964. Lahirnya UU No. 40 Tahun 2014 Tentang Perasuransian memberikan perubahan mendasar dalam pengelolaan dana pertanggungan wajib baik kecelakaan penumpang dan kecelakaan lalu lintas jalan akan dilaksanakan secara kompetitif sesuai dengan Pasal 39 ayat (1) UU Perasuransian.Metode yang digunakan yuridis normative berfokus pada inventarisasi hukum positif, asas-asas dan doktrin hukum, penemuan hukum dalam in concreto, sistematika hukum, taraf sinkronisasi hukum, perbandingan hukum. Temuan penelitian, (1) pelaksanaan bentuk penyesuaian PT. Jasa Raharja (Persero) penyesuaian tata kelola kelembagaan, penyesuaian bentuk badan hukum, Penyesuaian perihal perizinan dan pengawasan, (2) hambatan PT. Jasa Raharja dalam pelaksanaan UU No. 40 Tahun 2014 tentang Perasuransian yakni : hambatan dari segi pengaturan, pengelolaan dana, hambatan dari segi kelembagaan. Solusi: PT. Jasa Raharja (Pesero) koordinasi dengan pemerintah untuk penyempurnaan UU No. 40 Tahun 2014, Melakukan upaya penguatan kedudukan hukum dana pertanggungan wajib.

Kata Kunci : Asuransi, Jaminan Sosial, Korban Kecelakaan
\end{abstract}

\begin{abstract}
ABSTRACK
PT. Jasa Raharja (Persero) one of the State Owned Enterprises assigned by the government to manage the Passenger Compulsory Insurance Fund and Road Traffic Accident Fund as the implementation of Law no. 33 and 34 of 1964. The birth of Law no. 40 Year 2014 concerning Insurance shall provide fundamental changes in the management of the compulsory coverage of both passenger accidents and road traffic accidents to be carried out competitively in accordance with Article 39 paragraph (1) of the Insurance Law. The normative juridical method focuses on the inventory of positive law, legal principles and doctrines, the discovery of law in in concreto, legal systematics, the level of legal synchronization, comparative law. The research findings, (1) the implementation of the form of adjustment of PT. Jasa Raharja (Persero) adjustment of institutional governance, adjustment of legal entity form, Adjustment of permit and supervision. (2) Obstacles PT. Jasa Raharja in the implementation of Law no. 40 Year 2014 on Insurance namely: obstacles in terms of regulation, fund management, institutional constraints. Solution: PT. Jasa Raharja (Pesero) coordinates with the government for the improvement of Law no. 40 Year 2014, Conducting efforts to strengthen the legal standing of the mandatory sum insured.

Keywords: Insurance, Social Security, Accident Victims.
\end{abstract}

\section{PENDAHULUAN}

Pembangunan nasional memerlukan dan mengharuskan dilakukannya penyesuaian dalam 
berbagai hal terhadap perkembangan kondisi dan aspirasi masyarakat. Dalam industri perasuransian, baik secara nasional maupun global, terjadi perkembangan yang pesat yang ditandai dengan meningkatnya volume usaha dan bertambahnya pemanfaatan layanan jasa perasuransian oleh masyarakat. Layanan jasa perasuransian pun semakin bervariasi sejalan dengan perkembangan kebutuhan masyarakat akan pengelolaan risiko dan pengelolaan investasi yang semakin tidak terpisahkan, baik dalam kehidupan pribadi maupun dalam kegiatan usaha.

Selain perkembangan di dalam industri perasuransian, terjadi pula perkembangan di industri jasa keuangan yang lain. Perkembangan di berbagai industri jasa keuangan ini mengakibatkan semakin menipisnya batasan dan perbedaan jenis layanan yang diberikan oleh industri jasa keuangan. Perkembangan demikian menuntut adanya sistem pengaturan dan pengawasan sektor keuangan yang lebih baik dan terpadu.

Ketentuan yang ada dalam Undang-Undang Nomor 2 Tahun 1992 tentang Usaha Perasuransian (Lembaran Negara Republik Indonesia Tahun 1992 Nomor 13;Tambahan Lembaran Negara Republik Indonesia Nomor 3467) tidak lagi cukup untuk menjadi dasar pengaturan dan pengawasan industri perasuransian yang telah berkembang. Penyempurnaan terhadap peraturan perundang-undangan mengenai perasuransian harus dilakukan untuk menciptakan industri perasuransian yang lebih sehat, dapat diandalkan, amanah, dan kompetitif serta meningkatkan perannya dalam mendorong pembangunan nasional. ${ }^{1}$

Asuransi atau pertanggungan timbul karena kebutuhan manusia, bahwa dalam mengarungi kehidupan ini, manusia selalu dihadapkan sesuatu yang tidak pasti, yang mungkin menguntungkan, tetapi mungkin sebaliknya. Manusia mengharapkan kesehatan dan kesejahteraan tidak kurang suatu apapun, namun manusia hanya dapat berusaha, tetapi Tuhan Yang Maha Kuasa yang menentukan segalanya. Oleh karena itu, setiap insan tanpa kecuali di alam dunia ini selalu menghadapi berbagai resiko yang merupakan sifat yang hakiki manusia yang menunjukan ketidakberdayaan dibandingkan Sang Maha Pencipta Allah SWT. ${ }^{2}$

Usaha perasuransian merupakan kegiatan usaha yang bergerak di bidang usaha asuransi dan usaha penunjang usaha asuransi. Usaha asuransi yaitu usaha jasa keuangan yang dengan menghimpun dana masyarakat melalui pengumpulan premi asuransi memberikan perlindungan kepada anggota masyarakat pemakai jasa asuransi terhadap kemungkinan timbulnya kerugian karena suatu peristiwa yang tidak pasti atau terhadap hidup atau meninggalnya seseorang. Sedangkan usaha penunjang asuransi adalah usaha yang menyelenggarakan jasa keperantaraan, dan penilaian kerugian asuransi. ${ }^{3}$

Pengertian lain menurut J.C.T.Simorangkir Asuransi disebut Assurantie (Belanda) yang terdiri dari kata "assuradeur" yang berarti penanggung dan "geassureerde" yang berarti tertanggung. Kemudian dalam bahasa Perancis disebut "Asssurance" yang berarti menanggung sesuatu yang pasti terjadi. Sedangkan dalam bahasa latin disebut "Asecurace" yang berarti meyakinkan orang. Selanjutnya dalam bahasa Inggris kata asuransi disebut "Insurance" yang berarti menanggung sesuatu yang mungkin atau tidak mungkin terjadi dan "Assurance" yang berarti menanggung sesuatu yang pasti terjadi. ${ }^{4}$

Kecelakaan lalu lintas dari tahun ketahun semakin meningkat. Selain karena mobilitas atau

\footnotetext{
${ }^{1}$ Penjelasan Undang-Undang Nomor 40 Tahun 2014 Tentang Perasuransian

2 Man S. Sastrawidjaja, 2008, Aspek-aspek Hukum Asuransi dan Surat Berharga, Cetaka I, Alumni, Bandung, hal.1

${ }^{3}$ Kasmir, 2012, Hukum Asuransi Perlindungan Tertanggung Asuransi Deposito Usaha Perasuransian, Penerbit Alumni, Bandung, hal.263

4 J.C.T.Simorangkir,dkk, 2009, Kamus Hukum, Sinar Grafika, Jakarta, hal. 182
} 
banyaknya aktivitas masyarakat semakin meningkat, jumlah kendaraan bermotor juga semakin banyak. Hal ini menyebabkan jumlah korban jiwa karena kecelakaan baik darat, laut dan udara juga mengalami kenaikan. Oleh sebab itu Negara tidak hanya berperan dalam mencegah kecelakaan yang terjadi saat ini. Akan tetapi Negara harus memberikan jaminan bagi korban kecelakaan lalu lintas tersebut.

Pemerintah Indonesia harus memberikan jaminan terhadap korban kecelakaan, sehingga peran pemerintah sangat dibutuhkan (krusial). Karena korban kecelakaan dapat berasal dari berbagai unsur yang ada di masyarakat, terutama bagi golongan menengah kebawah, maka kehadiran untuk memberikan bantuan dalam bentuk jaminan sosial diberikan pada mereka yang mengalami kecelakaan lalu lintas dan kecelakaan penumpang angkutan umum.

Pada dasarnya penyelenggaraan jaminan sosial merupakan tugas pemerintah kepada masyarakat dalam bentuk iuran wajib dan sumbangan wajib masyarakat. Pengelolaan dan penguasaan dananya diserahkan kepada Badan Usaha Milik Negara (BUMN). BUMN disini adalah PT Jasa Raharja (Persero) sebagai Badan Usaha Milik Negara yang merupakan melaksanakan secara tunggal dalam penyelenggaraan jaminan sosial bagi kecelakaan penumpang angkutan umum dan kecelakaan lalu lintas jalan. Keberadaan PT. Jasa Raharja (Persero) tersebut tidak hanya dilihat semata-mata sebagai perusahaan asuransi dalam hal kecelakaan penumpang angkutan umum dan kecelakaan lalu lintas jalan. Akan tetapi PT Jasa Raharja (Persero) menjalankan peran dalam kehadiran Negara memberikan jaminan sosial.

Lahirnya UU No. 40 Tahun 2014 Tentang Perasuransian ini, ditunjukan untuk menciptakan industri perasuransian yang sehat, amanah, dan kompetitif. Penataan ini dalam kegiatan perasuransian dalam mendorong pembangunan nasional melalui dukungan perusahaan asuransi masyarakat dalam menghadapi resiko yang dihadapi. Penataan kegiatan usaha perasuransian dalam Undang-undang Nomor 40 Tahun 2014 Tentang Perasuransian, tidak saja kegiatan yang sukarela, tetapi juga menjadi program asuransi wajib. Pasal 39 ayat (1) menetapkan bahwa program asuransi wajib harus diselenggarakan secara kompetitif. Hal ini dapat di pahami bahwa penyelenggaraan program asuransi wajib diserahkan kepada mekanisme pasar dengan mengikutkan seluruh perusahaan asuransi, baik perusahaan Negara, maupun perusahaan asuransi swasta. ${ }^{5}$ Ketentuan Pasal 89 jika dilaksanakan, maka akan terjadi suatu perubahan mendasar dalam penyelenggaraan Dana Pertanggungan Wajib Kecelakaan Penumpang dan Dana Kecelakaan Lalu Lintas Jalan. Bahwa selama ini kedua pertanggungan Wajib diselenggarakan oleh perusahaan Negara (Badan Usaha Milik Negara) PT. Jasa Raharja (Persero).

\section{Metode Penelitian}

Penelitian ini berdasarkan pada penelitian hukum yang dilakukan dengan memakai Yuridis Normatif. Jenis penelitian yuridis Normatif (normative law research) menggunakan studi hukum normatif berupa produk perilaku hukum, misalnya mengkaji tentang rancangan undang-undang. Sehingga penelitian hukum normatif berfokus pada inventarisasi hukum positif, asas-asas dan doktrin hukum, penemuan hukum dalam in concreto, sistematika hukum, taraf sinkronisasi hukum, perbandingan hukum serta sejarah hukum. ${ }^{6}$ Sedangkan pendekatan yang dilakukan guna menjawab permasalahan penelitian ini adalah pendekatan perundang-undangan (statute

\footnotetext{
${ }^{5}$ Binsar Nasution, dkk, 2016, Jaminan Sosial Dalam Perspektif UU No.40 Tahun 2014 Tentang Perasuransian, Spora Consultant, Jakarta, hal.3

${ }^{6}$ Muhammad, Abdulkadir, 2007, Hukum dan Penelitian Hukum, PT. Citra Aditya Bakti Bandung, hal.52
} 
approach)..$^{7}$ Untuk menganalisis kaidah-kaidah hukum didalam perundang-undangan yakni, Undang-undang No. 40 Tahun 2014 Tentang Perasuransian, UU No.33 dan UU No. 34 Tahun 1964 Tentang Asuransi Sosial.

Spesifikasi dalam penelitian ini diskriptif analisis, diskriptif analitis artinya hasil penelitian ini berusaha memberikan gambaran secara menyeluruh, mendalam tentang suatu keadaan atau gejala yang diteliti. ${ }^{8}$ Dalam spesifikasi penelitian akan melihat pelaksanaan Undang-undang Nomor 40 Tahun 2014 Tentang Perasuransian khususnya pada Pasal 39 ayat (1) yang menyatakan penyelenggaraan asuransi wajib secara kompetitif, dalam arti dapat diselenggarakan oleh perusahaan perasuransian swasta.

Sumber data yang digunakan dalam penelitian ini meliputi ; Data Primer dan Data Sekunder, Data Primer ialah kata-kata dan tindakan orang-orang yang diamati atau diwawancarai. ${ }^{9}$ Sedangkan data sekunder ialah data yang terdiri dari 3 bahan hukum, antara lain bahan hukum primer, bahan hukum sekunder, dan bahan hukum tersier.

Penelitian ini dilakukan dengan menggunakan metode penelitian lapangan. ${ }^{10}$ Data yang dikumpulkan secara langsung dari sumbernya di tempat penelitian. Pada pengumpulan data secara primer, penulis menggunakan beberapa tehnik guna memperoleh data dengan observasi dan wawancara.

Analisis data menggunakan metode deskriptif analisis yang dapat digunakan dengan pendekatan kualitatif terhadap data primer dan sekunder, sehingga menggunakan pola pikir deduktif yang menganalisis Undang-undang Nomor 40 Tahun 2014 Tentang Perasuransian terhadap Jaminan Sosial Korban Kecelakaan Lalu Lintas (Studi kasus PT. Jasa Raharja (Persero) Cabang Jawa Tengah). Setelah pengumpulan data terkumpul kemudian data tersebut di analisis seperlunya agar diperoleh data yang matang dan akurat. ${ }^{11}$

\section{HASIL PENELITIAN DAN PEMBAHASAN}

Bentuk penyesuaian PT. Jasa Raharja (persero) pasca berlakunya Undang-undang Nomor 40 Tahun 2014 tentang Peransuransian terhadap Jaminan Sosial Korban Kecelakaan Lalu Lintas khususnya Pasal 39 ayat (1).

Pelayanan publik merupakan tanggung jawab pemerintah dan dilaksanakan oleh instansi pemerintah, baik itu pusat, didaerah, dan dilingkungan Badan Usaha Milik Negara. Masyarakat semakin terbuka dalam memberikan kritik bagi pelayanan publik. Oleh sebab itu substansi administrasi sangat berperan dalam mengatur dan mengarahkan seluruh kegiatan organisasi pelayanan dalam mencapai tujuan. Salah satu bentuk Pelayanan publik yang dilaksanakan oleh pemerintah adalah pemenuhan kebutuhan asuransi masyarakat. Pemerintah melalui UndangUndang Nomor 33 Tahun 1964 tentang Dana Pertanggungan Wajib Kecelakaan Penumpang dan Undang-Undang Nomor 34 Tahun 1964 tentang Dana Kecelakaan Lalu Lintas Jalan.

Mengemban amanah pemerintah sebagai pelaksana UU No. 33 dan UU No. 34 tahun 1964 yang harus menjamin kepastian dengan pemberian jaminan dalam pemerataan perlindungan para pengguna kendaraan, baik penumpang umum maupun pribadi, tentunya perkara yang tidak ringan. Semakin melonjaknya jumlah pengguna modal transportasi baik darat, laut, maupun udara

\footnotetext{
7 Ibid, hal. 14

${ }^{8}$ Soerjono Soekanto, 1986, Pengantar Penulisan Hukum, UI Press, Jakarta, hal.10

${ }^{9}$ Moleong, lexy, 1999, Metodologi Penelitian, PT.Remaja Rosada Karya, Bandung, hal.114hal.157

${ }^{10}$ Ali, Zainudin, 2009, Metodologi Penelitian Hukum, Sinar Grafika, Jakarta, hal.107

${ }^{11}$ Moleong, Op Cit, hal.288
} 
di satu sisi memang merupakan peluang karena akan secara otomatis meningkatkan jumlah premi yang masuk.

Guna menjamin kesejahteraan masyarakat terutama untuk meringankan beban hidup masyarakat akibat korban kecelakaan penumpang dan korban kecelakaan lalu lintas, pemerintah mendirikan perusahaan asuransi kecelakaan penumpang dan kecelakaan lalu lintas jalan. Sebagai wujud dari kehadiran Negara dalam membantu masyarakatnya dengan mendirikan Badan Usaha Milik Negara (BUMN) berupa PT. Jasa Raharja (Persero).

Pengertian Asuransi yang diatur dalam Pasal 246 Kitab Undang-Undang Hukum Dagang (KUHD) menjelaskan mengenai definisi pertanggungan bahwa "Pertanggungan adalah suatu perjanjian dengan mana penanggung mengikatkan diri kepada tertanggung dengan menerima premi, untuk memberikan penggantian kepadanya karena kerugian, kerusakan, atau kehilangan keuntungan yang diharapkan yang mungkin dideritanya akibat dari suatu evenemen" ${ }^{12}$

PT. Jasa Raharja mempunyai tugas dan tanggung jawab pokok dalam memberikan santunan kepada masyarakat yang mengalami kecelakaan lalu lintas sesuai ketentuan Undang-Undang Nomor 33 dan 34 Tahun 1964, dengan cara menghimpun dan mengelola iuran wajib dari penumpang alat angkutan umum darat, laut dan udara serta sumbangan wajib dari pemilik kendaran bemotor kepada korban kecelakaan maupun ahli waris korban kecelakaan lalu lintas jalan raya.

Undang-undang Nomor 40 Tahun 2014 Tentang Perasuransian mengubah cara pandang kehadiran negara dalam melindungi rakyatnya. Perlindungan terhadap rakyat Indonesia yang menjadi korban kecelakaan penumpang dan kecelakaan lalu lintas beralih sepenuhnya menjadi pasar terbuka. Hal ini dapat dilihat dari keberadaan UU Perasuransian yang menciptakan persaingan terbuka. Misalnya bisa dilihat dari pasal 7 ayat (2) UU Perasuransian menyebutkan bahwa warga Negara asing juga dapat berperan dalam menjalankan bisnis asuransi. Ketentua ini sudah jelas telah mengubah arah dan konsep perasuransian yang selama ini sudah berjalan, terutama mengenai peran Negara dalam melindungi rakyatnya yang menjadi korban kecelakaan penumpang dan kecelakaan lalu lintas. Kemudian peralihan itu menyebabkan kekuatan modal akan menjadi penentu daya saing pelayanan terhadap korban kecelakaan punumpang dan kecelakaan lalu lintas.

Pada pasal 39 ayat (1) UU Perasuransian yang menghendaki agar pelaksanaan asuransi wajib dilakukan secara kompetitif dan perintah Pasal 89 yang menuntut penyesuaian terhadap seluruh kententuan dalam peraturan perundang-undangan mewajibkan penutupan asuransi dan asuransi syariah oleh seluruh atau sekelompok tertentu dalam masyarakat dengan UU Nomor 40 Tahun 2014 Tentang Perasuransian.

Penyesuaian ini dalam kaitannya penyelenggaraan dana pertanggungan wajib berdasarkan UU No. 33 Tahun 1964 Tentang Kecelakaan Penumpang dan UU No. 34 Tahun 1964 Tentang Kecelakaan Lalu Lintas dengan kententuan UU No. 40 Tahun 2014 Tentang Perasuransian harus dilaksanakan secara hati-hati, agar dalam pelaksanaannya tidak menghilangkan kahadiran Negara (pemerintah) dalam melindungi masyarakat memberikan perlindungan dasar.

Asuransi berdasarkan UU No. 33 Tahun 1964 Tentang Kecelakaan Penumpang dan UU No. 34 Tahun 1964 Tentang Kecelakaan Lalu Lintas merupakan jenis asuransi sosial yang memberikan perlindungan dasar bagi warga masyarakat Indonesia yang mengalami kecelakaan angkutan umum dan kecelakaan lalu lintas jalan. Sebagai asuransi sosial, maka penanggungan dari asuransi sosial

\footnotetext{
${ }^{12}$ Pasal 246 Kitab Undang-undang Hukum Dagang (KUHD)
} 
ini harusnya Negara (pemerintah) atau badan yang ditunjuk oleh pemerintah. Oleh karena itu, tidak diselenggarakan secara kompetitif dijalankan oleh pihak swasta apabila dikaitkan dengan dengan Pasal 39 ayat (1) UU Perasuransian. Ada 4 (empat) jenis asuransi atau pertanggungan yang berbeda yakni :

1. Asuransi berdasarkan UU No. 33 Tahun 1964 Tentang Kecelakaan Penumpang dan UU No. 34 Tahun 1964 Tentang Kecelakaan lalu lintas yang meliputi perlindungan dasar terhadap kecelakaan yang dialami penumpang dan kecelakaan lalu lintas jalan.

2. Asuransi terhadap kerugian material yang diderita oleh penumpang atau pengirim barang berdasarkan Pasal 188 UU No. 22 Tahun 2009 Tentang Lalu Lintas dan Ankutan Jalan.

3. Asuransi kecelakaan sebagai wujud pertangung jawaban perusahaan angkutan umum atas jaminan asuransi bagi korban kecelakaan bedasarkan Pasal 237 ayat (1) UU No. 22 Tahun 2009 Tentang Lalu Lintas Jalan.

4. Asuransi bagi awak kendaraan yang dipekerjakan oleh perusahaan angkutan umum bersdasarkan Pasal 237 ayat (2) UU No. 22 Tahun 2009 Tentang Lalu Lintas Jalan. ${ }^{13}$

Dari uraian diatas, jika dikaitkan dengan pada kententuan Pasal 39 ayat (1) UU No. 40 Tahun 2014 yang memerintahkan penyelenggaraan asuransi wajib secara kompetitif dan perintah penyesuaian berdasarkan pada Pasal 89 UU Perasuransian, maka dapat disimpulkan, asuransi mana yang dari keempat jenis asuransi diatas yang harus dilaksanakan secara kompetitif.

Bisa disimpulkan bahwa asuransi berdasarkan UU No. 33 Tahun 1964 Tentang Kecelakaan Penumpang dan UU No. 34 Tentang Kecelakaan lalu lintas ini tidak termasuk dalam lingkup asuransi wajib sebagaimana dimaksud dalam UU No. 40 Tahun 2014 Tentang Perasuransian dengan pertimbangan bahwa, pertanggungan berdasarkan UU No. 33 dan 34 Tahun 1964 adalah bentuk pertanggungan atau jaminan sosial dalam skema asuransi (asuransi sosial). Karena Asuransi berdasarkan UU No. 33 dan 34 Tahun 1964 dilaksanakan berdasarkan asas gotong royong, dengan subsidi silang dari tertanggung yang memiliki kemampuan secara ekonomi kepada tertanggung yang tidak memiliki kemampauan secara ekonomi.

Sementara itu, UU No. 40 Tahun 2014 Tentang Perasuransian dan diperjelas dalam Peraturan Otoritas Jasa Keuangan Nomor 69/POJK.05/2016 Tentang Penyelenggaraan Usaha Perusahaan Asuransi, Perusahaan Asuransi Syariah, Perusahaan Reasuransi, dan Perusahaan Reasuransi Syariah, khususnya pada Pasal 5, 18, 26, 28, 29, 31, 39 ayat (3) sama sekali tidak mengenal dan tidak mengatur perihal pertanggungan atau asuransi sosial, UU Perasuransian hanya mengatur mengenai program asuransi wajib. ${ }^{14}$

Adapun penyesuaian dengan lahirnya UU Perasuransian jika nanti diterapkan secara kompetitif:

a. Penyesuaian bentuk badan hukum, Pasal 6 UU Perasuransian menetapkan bahwa bentuk badan usaha penyelenggaraan usaha perasuransian adalah badan hukum dalam bentuk perseroan terbatas, koperasi atau usaha bersama yang telah ada pada saat UU Perasuransian diundangkan. Bahwa sesuai karakteristik dana pertanggungan wajib berdasarkan UU No.33 dan 34 Tahun 1964 sebagai salah satu lembaga yang berbentuk jaminan social. Padahal PT. Jasa Raharja (Persero) sebagai penyelenggara yang ditunjuk oleh pemerintah adalah badan

\footnotetext{
${ }^{13}$ Hasil wawancara dengan Kepala Cabang PT. Jasa Raharja Jawa Tengah pada tanggal 20 Desember 2017 Pukul 09.17 Wib.

${ }^{14}$ Hasil wawancara dengan Kepala Cabang PT. Jasa Raharja Jawa Tengah pada tanggal 20 Desember 2017 Pukul 09.30 Wib.
} 
hukum bebentuk peseroan terbatas.

b. Penyesuaian penyelenggaraan usaha, sesuai dengan kententuan Pasal 11 UU No. 40 Tahun 2014 Tentang Perasuransian mewajibkan setiap perusahaan perasuransian untuk menerapkan tata kelola perusahaan yang baik. Penyesuaian penyelenggaraan usaha dengan berkwajiban melaksanakan Good Corporate Governance (GCG) tidak menimbulkan persoalan bagi penyelenggaraan dana pertanggungan wajib berdasarkan UU No. 33 dan 34 Tahun 1964, karena sebagai BUMN telah melakukan GCG berdasarkan UU BUMN.

\section{Hambatan PT. Jasa Raharja (Persero) dan solusinya dalam melaksanakan Undang-Undang Nomor 40 Tahun 2014 Tentang Peransuransian Terhadap Jaminan Sosial Korban Kecelakaan Lalu Lintas.}

Perkembangan moda transportasi darat membuat aktivitas manusia menjadi lebih mudah, tidak dapat dipungkiri semakin meningkatnya perkembangan transportasi darat terdapat pula risiko kecelakaan lalu lintas yang mengintai. Masyarakat sebagai warga Negara berhak mendapat perlindungan dan kepastian hukum. Negara memberikan kewenangannya kepada PT. Jasa Raharja (Persero) yang merupakan implementasi dari UU Nomor 33 Tahun 1964 dan UU Nomor 34 Tahun 1964.

Korban kecelakaan yang merupakan penumpang dari kendaraan umum, terjamin atau tidaknya didasarkan pada UU Nomor 33 Tahun 1964. Sedangkan untuk korban kecelakaan lalu lintas jalan yang bukan merupakan penumpang kendaraan umum, terjamin atau tidaknya didasarkan pada UU Nomor 34 Tahun 1964. Pelaksanaan asuransi korban kecelakaan lalu lintas pada dasarnya ditujukan kepada setiap orang yang mengalami kecelakaan lalu lintas dalam bentuk korban meninggal, luka-luka, cacat tetap berhak mendapatkan dana santunan kecelakaan ataupun ganti kerugian.

Peraturan perundang-undangan mengenai Asuransi yang baru yaitu Undang-undang Nomor 40 Tahun 2014 tentang Perasuransian. Undang-undang baru tersebut, menggantikan UndangUndang Nomor 2 Tahun 2014 tentang Usaha Perasuransian yang dinilai sudah tidak sesuai lagi dengan perkembangan industri perasuransian. Terdapat beberapa perubahan pokok dari UndangUndang Nomor 40 Tahun 2014 tentang Perasuransian ini dengan undang-undang yang lama, yaitu perubahan judul, dari semula Usaha Perasuransian menjadi Perasuransian.

Adanya perbedaan dalam UU No. 40 Tahun 2014 Tentang Perasuransian dan UU No. 33 Tahun 1964 Tentang Dana Pertanggungan Wajib Kecelakaan Penumpang dan UU No. 34 Tahun 1964 Tentang Dana Pertanggung Wajib Kecelakaan Lalu Lintas Jalan dalam penyelenggaraan dana pertanggungan wajib sebagai bentuk jaminan sosial yang berbeda dengan pelaksanaan asuransi pada umumnya. Hal ini juga akan merubah dalam penyesuaian terkait badan penyelenggara UU No. 33 dan 34 Tahun 1964. Adapun hambatan dalam pelaksanaan UU No. 40 Tahun 2014 Tentang Perasuransian yakni : ${ }^{15}$

1. Hambatan dalam segi pengaturan antara UU No. 33 dan 34 Tahun 1964 dengan UU No. 40 Tahun 2014 Tentang Perasuransian, hal ini bisa dilihat jika PT. Jasa Raharja (Persero) dalam melaksanakan penyelenggaraan dana pertanggungan wajib dari amanat UU No. 33 dan 34 Tahun 1964 yang mana undang-undang ini sebagai bentuk jaminan sosial yang berbeda dengan pelakasana (perusahaan) asuransi pada umumnya.

\footnotetext{
${ }^{15}$ Hasil wawancara dengan Kepala Cabang PT. Jasa Raharja Jawa Tengah pada tanggal 20 Desember 2017 Pukul 10.07 Wib.
} 
2. Hambatan dari segi kelembagaan, apabila kententuan pasal 89 UU perasuransian dilaksanakan, maka terjadi suatu perubahan mendasar dalam penyelenggaraan dana pertanggungan wajib kecelakaan penumpang dan kecelakaan lalu lintas jalan. Selama ini, kedua dana pertanggungan wajib diselenggarakan oleh perusahaan Negara (BUMN). Apabila harus disesuaikan dengan UU Perasuransian, maka yang dilakukan secara kompetitif.

3. Hambatan segi pengelolaan dana, dalam pratiknya penyelenggaraan UU No. 33 dan 34 Tahun 1964 dalam pembayaran sumbangan wajib bagi pemilik kendaraan dilakukan secara bersamaan dengan pembayaran pajak kendaraan yang dilaksanakan melaului SAMSAT yang melibatkan pemerintah pusat, pemerintah daerah, kepolisian dan PT. Jasa Raharja. Sistem ini memberikan kepastian terhadap kwajiban pemilik kendaraan untuk melaksanakan pembayaran iuran wajib. Kemudian dalam dana pertanggungan wajib berdasarkan UU No. 33 dan 34 Tahun 1964 tidak didasarkan pada suatu perjanjian atau kesepakatan tetapi diterapkan dalam peraturan perundang-undangan (hukum publik). Sedangkan di UU Perasuransian Pasal 28 UU Perasuransian menyebutkan bahwa premi atau kontribusi dapat dibayarkan langsung oleh pemegang polis atau peserta kepada perusahaan asuransi dan ditetapkan kesepakatan kepada para pihak yang disebutkan dalam perjanjian (polis asuransi).

Untuk mengatasi hambatan dengan lahirnya UU No. 40 Tahun 2014 Tentang Perasuransian salah satunya dengan langkah-langkah sebagai berikut :

a. PT. Jasa Raharja (Pesero) melakukan koordinasi kepada pemerintah untuk dilakukan penyempurnaan UU No. 40 Tahun 2014 Tentang Perasuransian mengenai kepastian kedudukan asuransi sosial yang termasuk didalamnya tata kelola pelaksanaan dengan memperhatikan keharmonisan UU Sistem Jaminan Sosial Nasional dan UU Badan Penyelenggara Jaminan Sosial.

b. Melakukan upaya penguatan kedudukan hukum dana pertanggungan wajib dan badan penyelenggaranya dengan memperbaharui UU No. 33 Tahun 1964 Tentang Kecelakaan Penumpang dan UU No. 34 Tahun 1964 Tentang Kecelakaan Lalu Lintas Jalan, sehingga kedudukannya sebagai dari sistem jaminan sosial nasional (SJSN) menjadi lebih berkepastian hukum.

c. Menigkantkan kompetensi SDM PT. Jasa Raharja dari segi hard skill maupun soft skill, agar terwujud dibidang pelayanan yang baik.

\section{KESIMPULAN}

1. Pelaksanaan bentuk penyesuaian PT. Jasa Raharja (persero) pasca berlakunya Undang-undang Nomor 40 Tahun 2014 tentang Peransuransian terhadap Jaminan Sosial Korban Kecelakaan Lalu Lintas khususnya Pasal 39 ayat (1) yaitu penyesuaian tata kelola kelembagaan, akan tetapi dalam faktanya penyelenggaraan dana pertanggungan wajib kecelakaan penumpang dan kecelakaan lalu lintas jalan sementara ini masih berjalan sebagai mana mestinya, berpedoman pada UU No. 33 dan 34 Tahun 1964. Karena belum ada kepastian hukum terhadap kedudukan dana pertanggungan wajib tersebut. Kemudian penyesuaian bentuk badan hukum dan Penyesuaian perihal perizinan dan pengawasan.

2. Hambatan PT. Jasa Raharja (Persero) dan solusi dalam melaksanakan Undang-Undang Nomor 40 Tahun 2014 Tentang Peransuransian Terhadap Jaminan Sosial Korban Kecelakaan Lalu Lintas, hambatan dalam segi pengaturan antara UU No. 33 dan 34 Tahun 1964 dengan UU No. 40 Tahun 2014 Tentang Perasuransian, hambatan segi kelembagaan, apabila kententuan pasal 
89 UU perasuransian dilaksanakan, maka terjadi suatu perubahan mendasar dalam penyelenggaraan dana pertanggungan wajib kecelakaan penumpang dan kecelakaan lalu lintas jalan. Selama ini, kedua dana pertanggungan wajib diselenggarakan oleh perusahaan Negara (BUMN). Hambatan segi pengelolaan dana, dalam pratiknya penyelenggaraan UU No. 33 dan 34 Tahun 1964 dalam pembayaran sumbangan wajib. Sedangkan UU Perasuransian Pasal 28 UU Perasuransian menyebutkan bahwa premi atau kontribusi dapat dibayarkan langsung oleh pemegang polis atau peserta. Solusi yakni : (1) PT. Jasa Raharja (Pesero) melakukan koordinasi kepada pemerintah untuk dilakukan penyempurnaan UU No. 40 Tahun 2014 Tentang Perasuransian, (2) Melakukan koordinasi kepada pemangku kepentingan mengenai dana pertanggungan wajib yang berdasarkan UU No. 33 dan 34 Tahun 1964, (3) Melakukan upaya penguatan kedudukan hukum dana pertanggungan wajib dan badan penyelenggaranya dengan memperbaharui UU No. 33 dan 34 Tahun 1964.

\section{DAFTAR PUSTAKA}

Ali, Zainudin, 2009. Metodologi Penelitian Hukum. Jakarta: Sinar Grafika.

Binsar Nasution, dkk. 2016. Jaminan Sosial Dalam Perspektif UU No.40 Tahun 2014 Tentang Perasuransian. Jakarta:Spora Consultant.

J.C.T.Simorangkir,dkk. 2009. Kamus Hukum. Jakarta:Sinar Grafika.

Kasmir. 2012. Hukum Asuransi Perlindungan Tertanggung Asuransi Deposito Usaha Perasuransian. Bandung:Penerbit Alumni.

Man S. Sastrawidjaja. 2008. Aspek-aspek Hukum Asuransi dan Surat Berharga. Cetaka I. Bandung: Alumni.

Muhammad, Abdulkadir. 2007. Hukum dan Penelitian Hukum. Bandung: PT. Citra Aditya Bakti.

Moleong, lexy. 1999. Metodologi Penelitian. Bandung: PT.Remaja Rosada Karya.

Soerjono Soekanto. 1999. Pengantar Penulisan Hukum. Jakarta:UI Press.

Kitab Undang-undang Hukum Dagang (KUHD)

Undang-Undang Nomor 40 Tahun 2014 Tentang Perasuransian 